\title{
Ten years of the Interuniversity Institute of Myology
}

\author{
Giorgio Fanò Illic $(1,2,3)$
}

(1) Department of Neurosciences \& Imaging, University "G. d'Annunzio" Chieti-Pescara, Italy; (2) ASI, Agenzia Spaziale Italiana, Roma, Italy; (3) IIM, Istituto Interuniversitario di Miologia, Italy

\begin{abstract}
The Interuniversity Institute of Myology (IIM) has been formally approved in late autumn 2003 by the University of Chieti Board of the first Director, Giorgio Fanò. Many Italian Myologists, coming from Italian Universities such as Università degli Studi di Chieti, Università degli Studi di Brescia, Università degli Studi di Firenze, Università degli Studi di Messina, Università degli Studi di Milano, Università degli Studi di Padova, Università degli Studi di Pavia, Università degli Studi di Perugia, Università degli Studi di Roma 'La Sapienza', Università degli Studi di Siena, who excel in Myology Research, recognized IIM and its potentiality for international joined collaboration.
\end{abstract}

Key Words: muscle physiology, biophysics, E-C coupling, homeostasis, differentiation, aging, atrophy, sarcopenia, cancer cachexia, stem and satellite cells, muscle dystrophies

European Journal Translational Myology - Basic Applied Myology 2013; 23 (4): 199-203

The Italian Interuniversity Institute of Myology (IIM) has been formally approved in late autumn 2003 by the University of Chieti. Its first Board of Directors was chaired by Giorgio Fanò Illic, who had the initiative and the strength to achieve this goal. Many Italian Myologists, coming from several Italian Universities such as Università degli Studi di Chieti, Università degli Studi di Brescia, Università degli Studi di Firenze, Università degli Studi di Messina, Università degli Studi di Milano, Università degli Studi di Padova, Università degli Studi di Pavia, Università degli Studi di Perugia, Università degli Studi di Roma 'La Sapienza', Università degli Studi di Siena, all prestigious institutions with strong tradition of Myology Research, joined and formally recognized IIM as the Italian Interuniversity Institute for Myology and its potentials for joined international collaboration. The Scientific Advisory Board, established to support the Director Giorgio Fanò Illic, was formed by Ugo Carraro with the role of Vice-Director and the elected

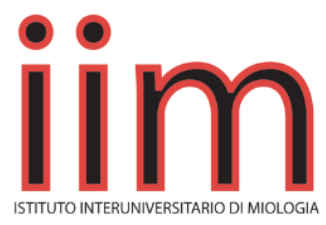

Fig 1. The logo members (R Bottinelli; P Bruni; G Cecchi; F Eusebi; F Felici; G Mazzoleni; A Musarò; C Orizio; F Protasi; C Reggiani; V Sorrentino; F Trimarchi; A Uncini; A Veicsteinas; P Volpe) from the five Research Units in which IIM was structured $a b$ origine.

More than ten years ago the main purpose of the project was to stimulate, set and strengthen relations among who were interested in research aspects of the vast field of myology. To reach this goal, collaborations between basic and applied researchers have to be set up, recognizing that it is a losing game to play in narrow and personal field. Essential part of this philosophy, was to establish "institutional paths" to allow young people to have many introductory ways to myology research, even after graduation, implementing coordinated $\mathrm{PhD}$, Internships, Specialization, etc. among the Courses already active in the IIM Universities.

During the past decade an Annual Meeting have always been organized, with a constant presence of more than one hundred researchers, particularly young fellows. Also thanks to these meetings about 240 papers were published in the most prestigious scientific Journals, in which the IIM appeared as affiliation of one or more authors. Some of these are randomly listed in the references section [1-16]. The latest edition of the meeting had reached the peak record of 68 abstracts pooled and discussed under the following topics proposed by the organizing committee: 


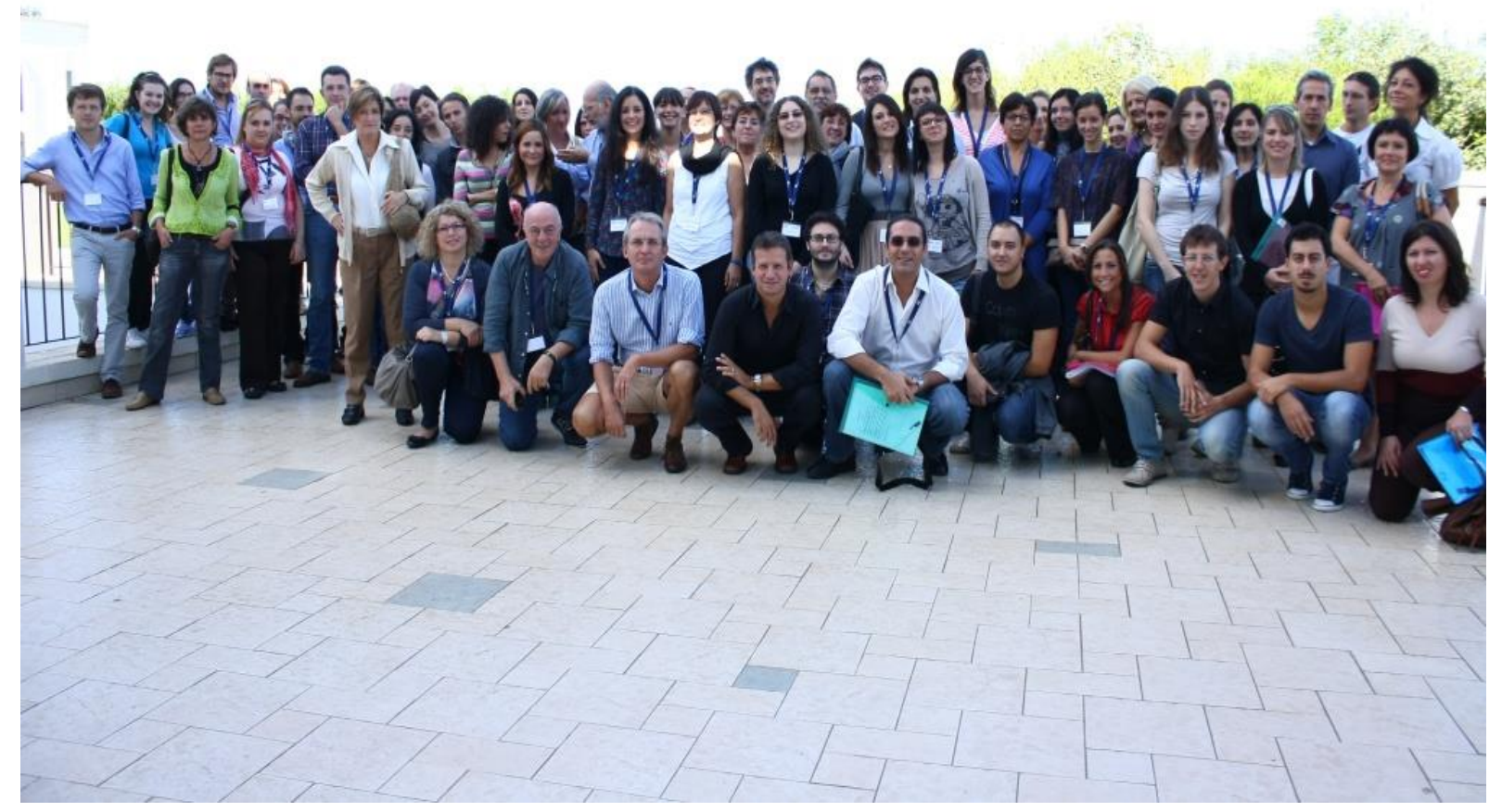

Fig 2. The vast majority of the participants of the IIM Meetings are very young. The few exception are Vincenzo Sorrentino, whose few-hair profile appears in the third row, and Giorgio Fano Illic knelt down in between Antonella D'Alfonso and Roberto Bottinelli. Near to them are Marco Sandri and Antonio Musarò. Who recognize her/his-self in this picture, is kindly requested to send an e-mail to the ejtmBAM Editor. IIM Board members are willing to record as many names as possible, in preparation for celebration of a future IIM Anniversary.

- Muscle physiology, biophysics and E-C coupling

- Regulation of muscle homeostasis and differentiation

- Satellite cells and muscle regeneration

- Muscle atrophy, sarcopenia and aging

- Muscle wasting and cancer cachexia

- Muscular dystrophies and related diseases

- New routes towards heart myogenesis

The audience in front of which the abstracts were discussed was made up of nearly 150 participants including many from several European Countries. The merits of such a success go not only to the last two directors that have been in charge during last years: Roberto Bottinelli and Antonio Musarò, but also to anyone, firstly being in the Advisory Board (M Sampaolesi, L Vitiello, D Rossi, MA Bagni, P Lorenzon, D Danieli-Betto, G Sorci, M Sandri, M Bizzarri, F Naro), who have helped to ensure the IIM become a sound scientific presence, and not only for Italy. The annual meetings are the IIM richness and power. They have been the means through which we have established knowledge and enthusiasm that have allowed us to both strength collaborations, and to "recruit" young researchers even in tough times like those we are now confronting.

During the last Meeting in Borgo San Luigi, Montiriggioni (Siena), between a "Ribollita" and a taste of "Cinta Senese" meats, Antonio Musarò was reelected director for another three years and, and with him was also selected the new Advisory Board on which are represented the elected members from the three research units in which IIM is organized today (E. Barbieri, G. Sorci; D. Gabellini; C. Mammucari; PL. Puri; B. Blaauw; S. Fulle; F. Grassi).

What we did, and have to do despite hard times:

- Grants for Post-doc: It's a small incentive, attractive for young people. We were able to establish this possibility only twice during the first 10 years. The second time only thanks to personal funds of generous members of the Scientific Council. In my opinion, every effort should be made to revive this possibility. 


\section{Interuniversity Institute of Myology (IIM)}

European Journal Translational Myology - Basic Applied Myology 2013; 23 (4): 199-203

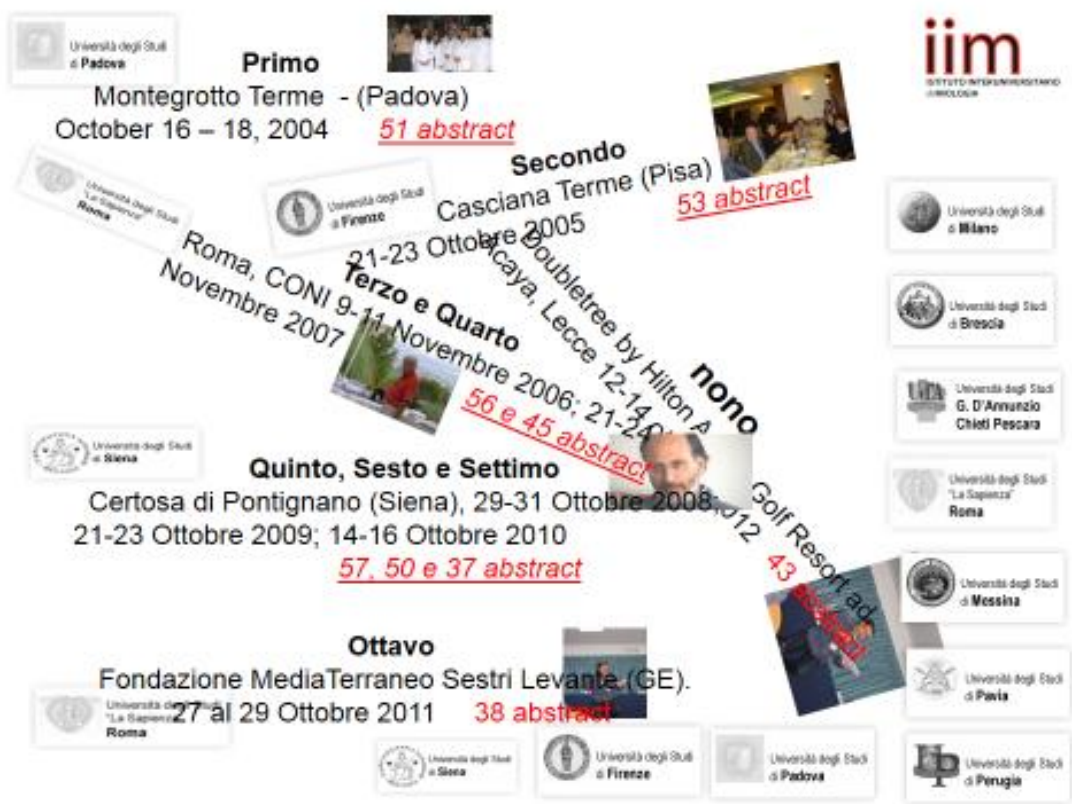

Fig 3. Along the first ten years annual meetings were organized by the showed colleagues.

What we were not able to implement:

- Specific funding for "IIM" projects: the only unrealized point of the original proposed program. However, even if we were not able to find new resources, collaboration among members of IIM has been extremely effective to obtain grants from public and private grant agencies.

- Editorial resources.

For various reasons (the main being the fact that, despite obtaining an Impact Factor, the Journal that is closer to us never achieved inclusion in

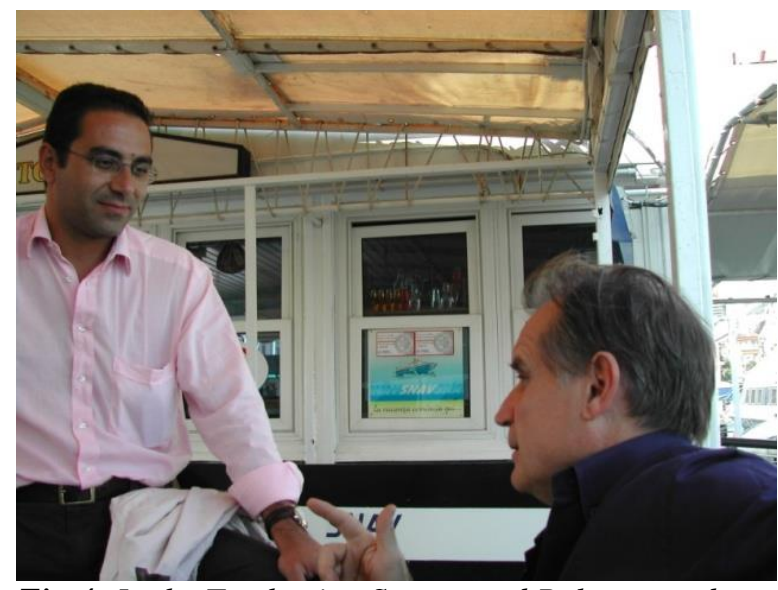

Fig 4. In the Tyrrhenian Sea toward Palermo and Stromboli for the prerelease of the IIM's birth, two of the future opinion leaders: Antonio Musarò (on the left) and Ugo Carraro discuss how to "kill" the boss-in-charge Giorgio Fanò Illic
PUBMED data base), our community of Myologists have not supported as much as we could the journal Basic and Applied Myology (BAM), now the European Journal of Translational Myology (EJTM), whose founder and editor, Ugo Carraro, is a founding partner of IIM (see Figure 4).

It is time, now, for all of us to look near to publish ideas, commentaries (wheter canonical or not), interim reports and conclusive results of our work and Graduation, Medical Specialty and $\mathrm{PhD}$ Thesis. Congratulations to all IIM members and ... see you soon, somewhere, for the next anniversary!

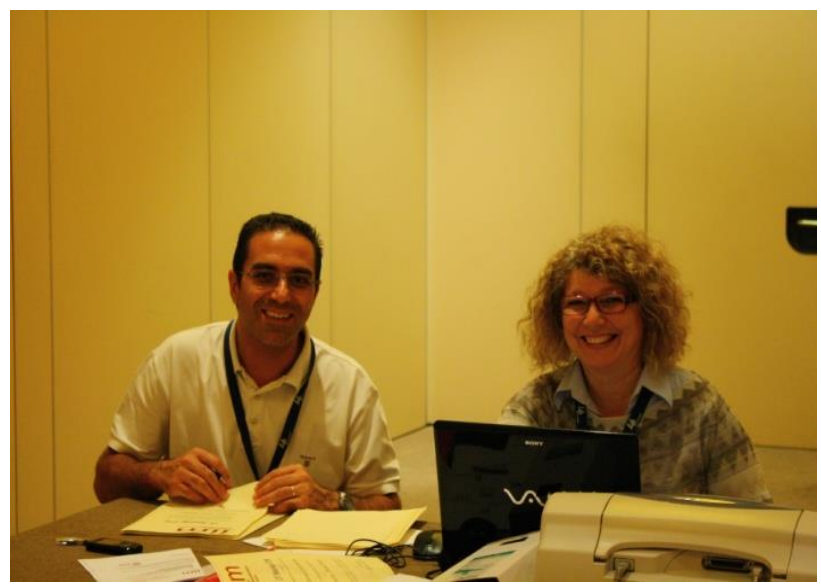

Fig 5. Twelve years later, Antonio Musarò, IIM Director-in-charge and Antonella D'Alfonso, IIM Secretary, prepare and signe Attendance Certificates of the 10th IIM Meeting, Borgo San Luigi, Monteriggioni (Siena), Italy, October 10-13, 2013 


\section{Interuniversity Institute of Myology (IIM)}

European Journal Translational Myology - Basic Applied Myology 2013; 23 (4): 199-203

\section{Acknowledgements}

Special thinks are due to the IIM secretary Antonella D'Alfonso (see Figure 3 and 5) and to the staff (Fabrizio Sabato as Web Master) that designed and implemented the IIM website. See the results at the link: http://www.coram-iim.it/

\section{Corresponding Author}

Giorgio Fanò Illic, Laboratory of Functional Evaluation, Department of Neuroscience \& Imaging, University of Chieti-Pescara, Chieti, Italy; E-mail: "Giorgio Fanò Illic" < fano@unich.it>

\section{References}

(Randomly choosed among 240 IIM citations)

[1] Abruzzo PM, di Tullio S, Marchionni C, Belia S, Fanó G, Zampieri S, Carraro U, Kern H, Sgarbi G, Lenaz G, Marini M. Oxidative stress in the denervated muscle. Free Radic Res 2010;44:563-576. doi: 10.3109/10715761003692487.

[2] Boncompagni S. Severe muscle atrophy due to spinal cord injury can be reversed in complete absence of peripheral nerves. European Journal Translational Myology - Basic Applied Myology 2012; 22: 161-200.

[3] Colombini B, Nocella M, Bagni MA, Griffiths PJ, Cecchi G. Is the cross-bridge stiffness proportional to tension during muscle fiber activation? Biophys J 2010;98:2582-2590. doi: 10.1016/j.bpj.2010.02.014.

[4] Dobrowolny G, Aucello M, Rizzuto E, Beccafico S, Mammucari C, Boncompagni S, Belia S, Wannenes F, Nicoletti C, Del Prete Z, Rosenthal N, Molinaro M, Protasi F, Fanò G, Sandri M, Musarò A. Skeletal muscle is a primary target of SOD1G93A-mediated toxicity. Cell Metab 2008;8:425-436. doi: 10.1016/j.cmet.2008.09.002. Erratum in: Cell Metab. 2009 Jan;9(1):110. Bonconpagni, Simona [corrected to Boncompagni, Simona].

[5] Donati C, Cencetti F, Nincheri P, Bernacchioni C, Brunelli S, Clementi E, Cossu G, Bruni P. Sphingosine 1-phosphate mediates proliferation and survival of mesoangioblasts. Stem Cells. 2007;25:1713-1719. Epub 2007 Apr 26.

[6] Gargiulo P, Reynisson PJ, Helgason B, Kern H, Mayr W, Ingvarsson P, Helgason T, Carraro U. Muscle, tendons, and bone: structural changes during denervation and FES treatment. Neurol Res. 2011; 33: 750-758. doi: 10.1179/1743132811Y.0000000007.

[7] Kern H, Carraro U, Adami N, Biral D Hofer C, Forstner C, Mödlin M, Vogelauer M, Boncompagni S, Paolini C, Mayr W, Protasi F, Zampieri S. Home-based Functional Electrical
Stimulation (h-b FES) recovers permanently denervated muscles in paraplegic patients with complete lower motor neuron lesion. Neurorehab Neur Rep 2010; 24: 709-721. doi: 10.1177/1545968310366129. Epub 2010 May 11.

[8] Kern H, Hofer C, Mayr W, Carraro U. European Project RISE: Partners, protocols, demography. Basic Appl Myol/ European Journal of Translational Myology 2009; 19: 211-216.

[9] Pellegrino MA, Desaphy JF, Brocca L, Pierno S, Camerino DC, Bottinelli R. Redox homeostasis, oxidative stress and disuse muscle atrophy. J Physiol 2011;589(Pt 9):2147-2160. doi: 10.1113/jphysiol.2010.203232. Epub 2011 Feb 14. Review.

[10] Pietrangelo T, Fioretti B, Mancinelli R, Catacuzzeno L, Franciolini F, Fanò G, Fulle S. Extracellular guanosine-5'-triphosphate modulates myogenesis via intermediate $\mathrm{Ca}(2+)$-activated $\mathrm{K}+$ currents in $\mathrm{C} 2 \mathrm{C} 12$ mouse cells. J Physiol 2006;572:721-733.

[11] Randazzo D, Giacomello E, Lorenzini S, Rossi D, Pierantozzi E, Blaauw B, Reggiani C, Lange S, Peter AK, Chen J, Sorrentino V. Obscurin is required for ankyrinB-dependent dystrophin localization and sarcolemma integrity. J Cell Biol 2013;200:523-536. doi: 10.1083/jcb.201205118.

[12] Riuzzi F, Sorci G, Sagheddu R, Donato R. HMGB1-RAGE regulates muscle satellite cell homeostasis through p38-MAPK- and myogenin-dependent repression of $\operatorname{Pax} 7$ transcription. J Cell Sci 2012;125(Pt 6):14401454. doi: $10.1242 /$ jcs.092163.

[13] Sampaolesi M, Blot S, D'Antona G, Granger N, Tonlorenzi R, Innocenzi A, Mognol P, Thibaud JL, Galvez BG, Barthélémy I, Perani L, Mantero S, Guttinger M, Pansarasa O, Rinaldi C, De Angelis MG, Torrente Y, Bordignon C, Bottinelli R, Cossu G. Corrigendum: Mesoangioblast stem cells ameliorate muscle function in dystrophic dogs. Nature 2013;494:506. doi: 10.1038/nature11976. Epub 2013 Feb 20.

[14] Scicchitano BM, Spath L, Musarò A, Molinaro M, Rosenthal N, Nervi C, Adamo S. Vasopressin-dependent myogenic cell differentiation is mediated by both $\mathrm{Ca} 2+/$ calmodulin-dependent kinase and calcineurin pathways. Mol Biol Cell 2005;16:3632-3641. Epub 2005 Jun 1.

[15] Squecco R, Carraro U, Kern H, Pond A, Adami $\mathrm{N}$, Biral D, Vindigni $\mathrm{V}$, Boncompagni $\mathrm{S}$, 


\section{Interuniversity Institute of Myology (IIM)}

European Journal Translational Myology - Basic Applied Myology 2013; 23 (4): 199-203

Pietrangelo T, Bosco G, Fanò G, Marini M, Abruzzo PM, Germinario E, Danieli-Betto D, Protasi F, Francini F, Zampieri S. A subpopulation of rat muscle fibers maintains an assessable excitation-contraction coupling mechanism after long-standing denervation despite lost contractility. J Neuropathol Exp Neurol 2009;68:1256-1268. doi: 10.1097/NEN.0b013e3181c18416.
[16] Zampieri S, Valente M, Adami N, Biral D, Ghirardello A, Rampudda ME, Vecchiato M, Sarzo G, Corbianco S, Kern H, Carraro U, Bassetto F, Merigliano S, Doria A. Polymyositis, dermatomyositis and malignancy: a further intriguing link. Autoimmun Rev 2010;9:449-453. doi: 10.1016/j.autrev.2009.12.005. Review. 